\title{
A comparison of Nordic Red, Holstein-Friesian and Finnish native cattle bulls for beef production and carcass traits
}

\author{
Arto Huuskonen \\ MTT Agrifood Research Finland, Animal Production Research, FI-92400 Ruukki, Finland, \\ e- mail: arto.huuskonen@mtt.fi
}

\begin{abstract}
The objective of this study was to determine beef production traits of purebred Nordic Red (NR), Holstein-Friesian (Hol), Eastern Finncattle (EF), Northern Finncattle (NF) and Western Finncattle (WF) bulls. The data collected from slaughterhouses included observations of 164862 NR, $87323 \mathrm{Hol}, 283 \mathrm{EF}, 523 \mathrm{NF}$ and $1728 \mathrm{WF}$ bulls. For estimating valuable cuttings also a separate dataset was collected including observations of $16036 \mathrm{NR}, 8806 \mathrm{Hol}, 18 \mathrm{EF}$, $126 \mathrm{NF}$, and $133 \mathrm{WF}$ bulls. NR and Hol had the highest carcass gain (532 and $542 \mathrm{~g} \mathrm{~d}^{-1}$, respectively). Overall, the data showed poorer gain of the Finnish native breeds compared to NR and Hol. Among the native breeds, WF (427 $\left.\mathrm{g} \mathrm{d}^{-1}\right)$ showed better growth compared to $\operatorname{EF}\left(356 \mathrm{~g} \mathrm{~d}^{-1}\right)$ and NF $\left(385 \mathrm{~g} \mathrm{~d}^{-1}\right)$. Less differences were observed in valuable cuttings as might be inferred based on the differences in carcass conformation scores.
\end{abstract}

Key words: beef production, bulls, dairy breeds, growth, carcass characteristics, Finncattle

\section{Introduction}

The majority of beef in Finland is produced by dairy breeds, and Nordic Red (NR) and Holstein-Friesian (Hol) are the two most frequently used breeds. The population structure of the NR dairy cattle is an admixture of Finnish Ayrshire, Danish Red and Swedish Red populations (Makgahlela et al. 2013). In addition, the gene pool of each of these three populations constitutes fractions from other breeds. The Finnish native cattle populations were named on the basis of their geographic breeding areas (Kantanen and Ojala 1994). Eastern Finncattle (EF) are usually brown-sided, Northern Finncattle (NF) are white with brown or black spots, and Western Finncattle (WF) are brown. According to Kantanen and Ojala (1994) EF, NF and WF could be regarded as three different native breeds. The number of Finnish native cattle cows has declined drastically. Kantanen and Ojala (1994) reported that still in 1970 there were 307600 Finncattle cows, but in 1980 their number had dropped to 42800 and in 1991 down to 7 900. In 2012 there were only approximately 1900 WF, 900 EF and 600 NF cows (Katarina Hägg, VikingGenetics Finland, personal communication and Jouko Yli-Uotila, Information Centre of the Ministry of Agriculture and Forestry, personal communication).

Based on a large slaughter data, Huuskonen et al. (2013) observed that the carcass gain of the NR heifers was $5 \%$ lower compared to the Hol heifers but the carcasses of the NR heifers were $12 \%$ better conformed. A similar study has not been conducted with NR and Hol bulls. Ruohomäki (1976) reported that Finnish native cattle $\times$ Friesian crossbreds had $9 \%$ higher live weight gain compared to pure Finnish native cattle bulls and heifers. However, there seems to be no scientific published information available on the relative growth performance and carcass traits of the Finnish native cattle compared to the other dairy breeds. The number of experimental animals is often limited when growth performance and carcass characteristics of different breed groups are compared in individual studies. Consequently, there is a concern about the representativeness of the experimental animals compared with other animals from the same breed groups, i.e. whether they cover the whole variation in their respective populations. Therefore, the present study is based on a large dataset collected from Finnish slaughterhouses. The objective was to investigate growth and carcass characteristics of NR, Hol, EF, NF and WF bulls in Finnish cattle population. 


\section{Materials and methods Dataset - complete slaughter data}

The dataset used in the present study was collected from four Finnish slaughterhouses Atria Ltd. (Seinäjoki, Finland), HK-Agri Ltd. (Turku, Finland), Saarioinen Lihanjalostus Ltd. (Tampere, Finland) and Snellman Lihanjalostus Ltd. (Pietarsaari, Finland). These slaughterhouses are the major meat companies in Finland, which, as a part of their business operations, transfer calves from dairy or suckler cow farms to co-operating farms for fattening, and slaughter the animals. All studied breed types present in the datasets from all four slaughterhouses.

Raw slaughter data for each animal included individual animal identification number on ear tag, date of birth, date of slaughter, sex, carcass weight, carcass conformation score and carcass fat score. Identities of breeds (dam and sire breed) were collected from the National Animal Identification Register for Cattle (ProAgria Agricultural Data Processing Centre, P.O. Box 25, FI-01301 Vantaa, Finland). Slaughtering data and identities of breeds for individual animals were linked through individual animal identification numbers. All purebred NR, Hol, EF, NF and WF bulls slaughtered by above-mentioned slaughterhouses in 2009-2011 were selected for the study but the bulls slaughtered under 365 or above 730 days of age were excluded.

After slaughter the carcasses were weighed hot in all of the slaughterhouses. The cold carcass weight was estimated as 0.98 of the hot carcass weight. The carcasses were classified for conformation and fatness using the EUROP quality classification (EC 2006). For conformation, development of carcass profiles, in particular the essential parts (round, back, shoulder), was taken into consideration according to the EUROP classification (E: excellent, U: very good, R: good, O: fair, P: poor), and for fat cover, the amount of fat on the outside of the carcass and in the thoracic cavity was taken into account using a classification range from 1 to 5 (1: low, 2: slight, 3: average, 4: high, 5: very high). Each level of the conformation scale was subdivided into three sub-classes (e.g. O+, O, O-) to produce a transformed scale ranging from 1 to 15 , with 15 being the best conformation. Carcass classifications were carried out by trained slaughterhouse personnel.

Birth weight assumptions used in calculations were $40 \mathrm{~kg}$ live weight and $16 \mathrm{~kg}$ carcass weight for all bull calves, since the same values were used by Atria Ltd. in daily extension work (Herva et al. 2009, 2011). The birth weight of the Finncattle calves may have been slightly smaller than that of the conventional dairy breeds, but unfortunately no data was available to estimate it, and the effect of it on estimated daily gains would be negligible. An estimated daily carcass gain was calculated by subtracting $16 \mathrm{~kg}$ birth carcass weight from the reported carcass weight and dividing the result by age at slaughter. The complete final slaughter data comprised 254671 slaughtered bulls; the average slaughter age was 590 days and the mean carcass weight $330 \mathrm{~kg}$ (Table 1). The average estimated daily carcass gain was $534 \mathrm{~g} \mathrm{~d}^{-1}$, the EUROP conformation score 4.5 and the carcass fat score 2.4.

\section{Dataset - commercial cutting}

For estimating valuable cuttings for studied breeds a separate dataset was collected in 2010-2011 from Snellman Lihanjalostus Ltd. In addition to above-mentioned variables this dataset included also information on commercial cuttings. Each carcass was cut into valuable cuts: outside round (Musculus semitendinosus), inside round Musculus semimembranosus), corner round (Musculus quadriceps femoris), roast beef (Musculus gluteus medius), tenderloin (Musculus psoas major) and loin (Musculus longissimus)] and tallow (subcutaneous fat) as described by Pesonen et al. $(2012,2013)$. The amount of tallow was evaluated by cutting off the visible subcutaneous fat on the surface of primal cuts and by weighing the yield of tallow in grams. All these cuttings were weighed automatically in line and their yields were expressed as percentages of the carcass cold weight $(0.98 \times$ carcass hot weight, 50 min post mortem). This dataset comprised 25119 slaughtered bulls (Table 1). The average daily carcass gain and mean carcass weight were 4 and 3\% lower than those in the complete slaughter data, respectively, but the average conformation and fat scores were almost the same in both datasets (Table 1).

\section{Statistical methods}

The results are shown as least squares means. The normality of residuals and the homogeneity of variances were checked using graphical methods: box-plots and scatter plots of residuals and fitted values. The data were subjected to the analysis of variance using the SAS Mixed procedure (version 9.2, SAS Institute Inc., Cary, NC), and a fixed effect of breed was used in the statistical model. Differences between the breeds were compared using Tukey's $t$-test. 
Table 1. Description of the experimental data.

\begin{tabular}{|c|c|c|c|c|c|}
\hline Variable & $\mathrm{n}$ & Mean & SD & $\mathrm{q}_{0.05}$ & $\mathrm{q}_{0.95}$ \\
\hline \multicolumn{6}{|l|}{ Dataset, complete slaughter data } \\
\hline Age at slaughter, $d$ & 254671 & 590 & 62.2 & 489 & 699 \\
\hline Carcass gain, $\mathrm{g} \mathrm{d}^{-1}$ & 254671 & 534 & 79.2 & 398 & 655 \\
\hline Carcass weight, kg & 254671 & 330 & 49.1 & 245 & 405 \\
\hline Conformation score, EUROP & 254240 & 4.50 & 1.010 & 3 & 6 \\
\hline Fat score, EUROP & 254641 & 2.41 & 0.640 & 2 & 3 \\
\hline \multicolumn{6}{|l|}{ Dataset, commercial cutting } \\
\hline Age at slaughter, $d$ & 25119 & 591 & 67.2 & 478 & 703 \\
\hline Carcass gain, $\mathrm{g} \mathrm{d}^{-1}$ & 25119 & 515 & 77.2 & 381 & 633 \\
\hline Carcass weight, kg & 25119 & 319 & 47.6 & 237 & 391 \\
\hline Conformation score, EUROP & 25119 & 4.54 & 0.870 & 3 & 6 \\
\hline Fat score, EUROP & 25119 & 2.47 & 0.650 & 2 & 4 \\
\hline \multicolumn{6}{|l|}{ From yield, $\mathrm{g} \mathrm{kg}^{-1}$} \\
\hline Subcutaneous fat & 25119 & 47.2 & 14.71 & 25.8 & 73.4 \\
\hline Musculus longissimus & 24052 & 37.4 & 3.29 & 32.7 & 42.1 \\
\hline Musculus psoas major & 24081 & 13.6 & 1.24 & 11.9 & 15.5 \\
\hline Musculus semimembranosus & 24543 & 36.9 & 3.54 & 31.7 & 42.6 \\
\hline Musculus semitendinosus & 24562 & 57.2 & 5.20 & 49.8 & 64.2 \\
\hline Musculus quadriceps femoris & 24605 & 34.8 & 2.96 & 30.6 & 39.4 \\
\hline Musculus gluteus medius & 24685 & 17.0 & 1.85 & 14.4 & 19.9 \\
\hline
\end{tabular}

$\mathrm{SD}=$ Standard deviation.

0.05 -quantile (approximately $5 \%$ of the data has a value less than the 0.05 -quantile).

0.95 -quantile (approximately $95 \%$ of the data has a value less than the 0.95 -quantile).

Conformation score: ( $1=$ poorest, $15=$ excellent).

Fat score: ( $1=$ leanest, $5=$ fattest $)$.

Musculus longissimus $=$ loin.

Musculus psoas major = tender loin.

Musculus semimembranosus $=$ inside round.

Musculus semitendinosus = outside round.

Musculus quadriceps femoris = corner round.

Musculus gluteus medius $=$ roast beef.

\section{Results and discussion}

The complete slaughter data included 164812 and 87323 purebred NR and Hol bulls, respectively (Table 2). The most popular native breed was WF (1 728 observations), while NF (525) and EF (283) had lower numbers. The average slaughter age for purebred NR bulls was 592 days. The slaughtered Hol bulls were 5 days younger than the NR bulls $(p<0.001)$. In the WF bulls the average slaughter age did not differ from the NR and Hol bulls but the EF and NF bulls were slaughtered slightly younger (Table 2 ). Typically all bull calves transferred from dairy farms are housed and fed consistently in finishing farms i.e. different methods are not used for different breeds within a finishing farm in Finland. Therefore it can be assumed that the results of the present data represent well the differences between the breed groups in Finnish cattle population.

The average daily carcass gain and carcass weight showed clearly differences among breeds, and all breed groups differed significantly from each other (Table 2). NR and Hol had the highest carcass gain (532 and $542 \mathrm{~g} \mathrm{~d}^{-1}$, respectively) and carcass weight ( 330 and $333 \mathrm{~kg}$ ). EF and NF had the lowest carcass gain (356 and $385 \mathrm{~g} \mathrm{~d}^{-1}$ ) and carcass weight (219 and $238 \mathrm{~kg}$ ), whereas WF, had an intermediate gain ( $427 \mathrm{~g} \mathrm{~d}^{-1}$ ) and carcass weight (269 kg). It is interesting to note that the ranking of the three Finncattle breeds was the same in daily carcass gain and slaughter weight as it is in milk production (Nokka 2014). 
Table 2. Carcass gain, carcass characteristics and valuable cuts of Nordic Red (NR), Holstein-Friesian (Hol), East-Finnish cattle (EF), North-Finnish cattle (NF) and West-Finnish cattle (WF) bulls in Finnish slaughter dataset. Between-breeds comparisons (Tukey, $p<0.05)$ : estimated means with the different letters were significantly different $(p<0.05)$.

\begin{tabular}{|c|c|c|c|c|c|c|c|}
\hline & \multicolumn{6}{|c|}{ Breed } & \multirow[b]{2}{*}{$p$ value } \\
\hline & NR & $\mathrm{Hol}$ & $\mathrm{EF}$ & NF & WF & SEM & \\
\hline \multicolumn{8}{|l|}{ Dataset, complete slaughter data } \\
\hline Number of animals & 164812 & 87323 & 283 & 525 & 1728 & - & - \\
\hline Age at slaughter, $d$ & $592^{\mathrm{a}}$ & $587^{\mathrm{b}}$ & $568^{c}$ & $573^{d}$ & $591^{\mathrm{ab}}$ & 3.7 & $<0.001$ \\
\hline Carcass gain, $\mathrm{g} \mathrm{d}^{-1}$ & $532^{\mathrm{a}}$ & $542^{\mathrm{b}}$ & $356^{c}$ & $385^{d}$ & $427^{e}$ & 4.6 & $<0.001$ \\
\hline Carcass weight, kg & $330^{\mathrm{a}}$ & $333^{b}$ & $219^{c}$ & $238^{d}$ & $269^{e}$ & 2.9 & $<0.001$ \\
\hline Conformation, EUROP & $4.71^{\mathrm{a}}$ & $4.14^{\mathrm{b}}$ & $3.39^{c}$ & $3.54^{\mathrm{cd}}$ & $3.57^{d}$ & 0.058 & $<0.001$ \\
\hline Fat score, EUROP & $2.43^{\mathrm{a}}$ & $2.38^{\mathrm{b}}$ & $2.49^{\mathrm{ac}}$ & $2.51^{c}$ & $2.47^{\mathrm{ac}}$ & 0.038 & $<0.001$ \\
\hline \multicolumn{8}{|l|}{ Dataset, commercial cutting } \\
\hline Number of animals & 16036 & 8806 & 18 & 126 & 133 & - & - \\
\hline Age at slaughter, $d$ & $592^{a}$ & $589^{b}$ & $641^{c}$ & $561^{d}$ & $606^{\mathrm{ac}}$ & 15.8 & $<0.001$ \\
\hline Carcass gain, $\mathrm{g} \mathrm{d}^{-1}$ & $513^{a}$ & $521^{b}$ & $375^{\text {cd }}$ & $389^{c}$ & $416^{d}$ & 18.0 & $<0.001$ \\
\hline Carcass weight, kg & $318^{a}$ & $321^{b}$ & $254^{\text {cd }}$ & $234^{c}$ & $268^{d}$ & 11.1 & $<0.001$ \\
\hline Conformation, EUROP & $4.76^{a}$ & $4.16^{\mathrm{b}}$ & $4.44^{\mathrm{ab}}$ & $3.88^{c}$ & $3.91^{c}$ & 0.194 & $<0.001$ \\
\hline Fat score, EUROP & $2.49^{\mathrm{a}}$ & $2.42^{\mathrm{b}}$ & $2.94^{c}$ & $2.49^{\mathrm{ab}}$ & $2.51^{\mathrm{ab}}$ & 0.153 & $<0.001$ \\
\hline \multicolumn{8}{|l|}{ From carcass yield, $\mathrm{g} \mathrm{kg}^{-1}$} \\
\hline Subcutaneous fat & $47.3^{\mathrm{a}}$ & $46.9^{\mathrm{a}}$ & $56.6^{\mathrm{b}}$ & $50.0^{\mathrm{ab}}$ & $49.3^{\mathrm{ab}}$ & 3.47 & $<0.001$ \\
\hline Musculus longissimus & $37.9^{\mathrm{a}}$ & $36.5^{\mathrm{b}}$ & $38.9^{\mathrm{ac}}$ & $39.4^{c}$ & $38.6^{\mathrm{ac}}$ & 0.72 & $<0.001$ \\
\hline Musculus psoas major & $13.6^{a}$ & $13.7^{\mathrm{b}}$ & $13.4^{\mathrm{ab}}$ & $13.8^{\mathrm{ab}}$ & $13.6^{\mathrm{ab}}$ & 0.28 & $<0.001$ \\
\hline Musculus semimembranosus & $36.1^{\mathrm{a}}$ & $38.2^{\mathrm{b}}$ & $34.2^{c}$ & $36.6^{a}$ & $36.1^{\mathrm{ac}}$ & 0.76 & $<0.001$ \\
\hline Musculus semitendinosus & $56.6^{a}$ & $58.3^{\mathrm{b}}$ & $52.3^{c}$ & $52.3^{c}$ & $53.7^{c}$ & 1.15 & $<0.001$ \\
\hline Musculus quadriceps femoris & $34.0^{\mathrm{a}}$ & $36.2^{\mathrm{b}}$ & $30.9^{c}$ & $34.5^{\mathrm{a}}$ & $34.6^{\mathrm{a}}$ & 0.64 & $<0.001$ \\
\hline Musculus gluteus medius & $16.7^{\mathrm{a}}$ & $17.7^{\mathrm{b}}$ & $16.1^{\mathrm{a}}$ & $16.8^{\mathrm{a}}$ & $16.8^{\mathrm{a}}$ & 0.40 & $<0.001$ \\
\hline
\end{tabular}

SEM = standard error of the mean.

Conformation score: (1 = poorest, 15 = excellent).

Fat score: ( 1 = leanest, 5 = fattest).

Musculus longissimus $=$ loin.

Musculus psoas major $=$ tender loin.

Musculus semimembranosus = inside round.

Musculus semitendinosus = outside round.

Musculus quadriceps femoris = corner round.

Musculus gluteus medius = roast beef.

Lifetime daily carcass gain ( $534 \mathrm{~g} \mathrm{~d}^{-1}$, on average) observed in the present data was in line with the observations reported by Herva et al. (2009) (538 $\mathrm{g} \mathrm{d}^{-1}$ ) based on results of 55375 dairy bull calves delivered by Atria Ltd. in 2003. Compared to the recent Finnish experimental datasets for dairy bulls with typical Finnish grass silage-based diets (e.g. Huuskonen and Joki-Tokola 2010, Huuskonen et al. 2011, Huuskonen 2009, 2011, 2013), the average lifetime carcass gain was approximately $10 \%$ lower in the present field data. This difference probably reflects variable feeding regimes and management factors at farm level compared to the controlled experimental environments. In addition, the mentioned experimental datasets included only NR and Hol bulls and not native breed bulls. Based on a dataset with purebred Hol and NR heifers, Huuskonen et al. (2013) reported that the average daily carcass gain of the Hol heifers was $5 \%$ higher compared to the NR heifers which is slightly greater difference than observed in the present study using $\mathrm{Hol}$ and NR bulls.

The EUROP conformation score of the Hol bulls was lower compared to the NR bulls $(p<0.001)$ (Table 2), which is in line with the earlier research using NR and Hol heifers (Huuskonen et al. 2013). The carcasses of the native breeds conformed clearly poorer compared to NR and Hol. The WF bulls produced better conformed carcasses compared to the EF bulls $(p<0.05)$ but there were no significant differences between EF and NF or between NF and WF in carcass conformation. The carcass fat score of the NR bulls was higher than that of the Hol bulls $(p<0.001)$. Furthermore, the fat score of the native breeds was higher compared to $\mathrm{Hol}(p<0.05)$ but there were no significant differences among the native breeds in carcass fat score. 
Dataset from commercial cuttings included 16 036, 8 806, 133 and 126 purebred NR, Hol, WF and NF bulls, respectively. The amount of the EF bulls was limited (18) in this dataset and carcass weight of the EF bulls was $35 \mathrm{~kg}$ higher compared to the complete slaughter data (Table 2). Therefore, the results of the EF bulls in cutting parameters could be biased. Breed had clear effects on the yield of valuable cuts. The yields of tenderloin, inside round, outside round, corner round and roast beef were higher in Hol than in NR $(p<0.001)$ (Table 2). On the contrary, the yield of loin was $4 \%$ higher in NR compared to $\mathrm{Hol}(p<0.001)$. There was no significant difference in the yield of subcutaneous fat between the NR and Hol bulls.

The yield of loin was higher in the NF bulls compared to the NR and Hol bulls $(p<0.001)$ and in the EF and WF bulls compared to the Hol bulls $(p<0.05)$. There were no differences in the yield of tender loin when the native breed groups were compared to NR and Hol or among the native breeds (Table 2). The yield of inside round was higher in Hol compared to native breeds. Furthermore, the yield of inside round was higher in NR and NF compared to EF. Concerning outside round the yield was higher in NR and Hol compared to the native breeds and there were no differences among the native breeds. The yield of corner round was higher in the Hol bulls compared to native breed bulls. Furthermore, the yield of corner round was higher in the NR, WF and NF bulls compared to the EF bulls. The yield of roast beef was higher in Hol compared to native breeds but there was no difference between NR and native breeds or among the native breeds (Table 2). There were no significant differences in the yield of subcutaneous fat when comparing NR and Hol to NF and WF. However, the yield of subcutaneous fat was higher in EF compared to NR and $\mathrm{Hol}(p<0.05)$.

Aass and Vangen (1998) suggested that commercial conformation grading is in general an imprecise method for evaluation of carcass composition. Also in the present study the differences in conformation score suggested a superior muscling of the NR bulls compared to the Hol and native breed bulls. However, in terms of valuable cuts there were only limited differences between NR and native breeds. In addition, the yields of many valuable cuts were higher in Hol than in NR. In general, carcass conformation and fat scores have explained moderate to high proportions of the variation ( $R^{2}$ ranged from 0.47 to 0.70 ) in carcass meat yield (Perry et al. 1993, Drennan et al. 2008, Conroy et al. 2009, 2010). Craigie et al. (2012) reported how point changes in the EUROP grid relate to changes in the yield of lean meat in the whole beef carcass as well as in to the yield of high value cuts relative to carcass weight. Studies summarized by Craigie et al. (2012) indicated that the percentage of variation $\left(R^{2}\right.$ range 0.55-0.75) in carcass lean meat yield explained by the EUROP grid was much greater using the entire carcass than using high-value cuts only $\left(R^{2}\right.$ range $\left.0.28-0.57\right)$. While these high-value cuts are a small percentage of the carcass lean meat yield, they account for a large proportion of carcass value. Craigie et al. (2012) concluded that there is a clear need for an accurate commercial measurement or prediction methods for true value of the carcasses which is supported also by the present data.

Overall, the present data showed that the carcass gain of the NR bulls was slightly lower compared to the Hol bulls but the carcasses of the NR bulls were better conformed compared to the Hol bulls. Furthermore, poorer growth performance of the Finnish native breeds compared to the NR and Hol breeds was observed. Among the native breeds, WF showed better growth compared to EF and NF. Less differences in valuable cuttings were observed as might be inferred based on the differences in carcass conformation scores.

\section{Acknowledgements}

The study was partially funded by the Centre for Economic Development, Transport and the Environment for North Savo, Atria Ltd., HK-Agri Ltd., Saarioinen Lihanjalostus Ltd. and Snellman Lihanjalostus Ltd. I would like to thank Ms. Maarit Hyrkäs for the data processing and statistical analyses. I wish to express my gratitude to Prof. Marketta Rinne for useful comments on the manuscript.

\section{References}

Aass, L. \& Vangen, O. 1998. Carcass and meat quality characteristics of young bulls of Norwegian cattle and crossbreds with Angus, Hereford and Charolais. Acta Agriculturae Scandinavica, Section A, Animal Science 48: 65-75.

Conroy, S.B., Drennan, M.J., Kenny, D.A. \& McGee, M. 2009. The relationship of live animal muscular and skeletal scores, ultrasound measurements and carcass classification scores with carcass composition and value in steers. Animal 3: 1613-1624.

Conroy, S.B., Drennan, M.J., Kenny, D.A. \& McGee, M. 2010. The relationship of various muscular and skeletal scores and ultrasound measurements in the live animal, and carcass classification scores with carcass composition and value of bulls. Livestock Science 127: 11-21. 
Craigie, C.R., Navajas, E.A., Purchas, R.W., Maltin, C.A., Bünger, L., Hoskin, S.O., Ross, D.W., Morris, S.T. \& Roehe, R. 2012. A review of the development and use of video image analysis (VIA) for beef carcass evaluation as an alternative to the current EUROP system and other subjective systems. Meat Science 92: 307-318.

Drennan, M.J., McGee, M. \& Keane, M.G. 2008. The value of muscular and skeletal scores in the live animal and carcass classification scores as indicators of carcass composition in cattle. Animal 2: 752-760.

EC 2006. Council Regulation (EC) No 1183/2006 of 24 July 2006 concerning the Community scale for the classification of carcasses of adult bovine animals. The Official Journal of the European Union L, 214: 1-6.

Herva, T., Huuskonen, A., Virtala, A.-M. \& Peltoniemi, O. 2011. On-farm welfare and carcass fat score of bulls at slaughter. Livestock Science 138: 159-166.

Herva, T., Virtala, A-M., Huuskonen, A., Saatkamp, H. W. \& Peltoniemi, O. 2009. On-farm welfare and estimated daily carcass gain of slaughtered bulls. Acta Agriculturae Scandinavica, Section A, Animal Science 59: 104-120.

Huuskonen, A. 2009. The effect of cereal type (barley versus oats) and rapeseed meal supplementation on the performance of growing and finishing dairy bulls offered grass silage-based diets. Livestock Science 122: 53-62.

Huuskonen, A. 2011. Effects of barley grain compared to commercial concentrate or rapeseed meal supplementation on performance of growing dairy bulls offered grass silage-based diet. Agricultural and Food Science 20: 191-205.

Huuskonen, A. 2013. Performance of growing and finishing dairy bulls offered diets based on whole-crop barley silage with or without protein supplementation relative to a grass silage-based diet. Agricultural and Food Science 22: 424-434.

Huuskonen, A., Huumonen, M., Joki-Tokola, E. \& Tuomisto, L. 2011. Effects of different liquid feeding strategies during the pre-weaning period on the performance and carcass characteristics of dairy bull calves. Acta Agriculturae Scandinavica, Section A, Animal Science 61: 187-195.

Huuskonen, A. \& Joki-Tokola, E. 2010. Performance of growing dairy bulls offered diets based on silages made of whole-crop barley, whole-crop wheat, hairy vetch and grass. Agricultural and Food Science 19: 116-126.

Huuskonen, A., Pesonen, M., Kämäräinen, H. \& Kauppinen, R.. 2013. A comparison of the growth and carcass traits between dairy and dairy $\mathrm{x}$ beef breed crossbred heifers reared for beef production. Journal of Animal and Feed Sciences 22: 188-196.

Kantanen, J. \& Ojala, M. 1994. Blood group and protein polymorphism in the Finnish native cattle populations. Agricultural Science in Finland 3: 169-176.

Makgahlela, M.L., Mäntysaari, E.A., Stranden, I., Koivula, M., Nielsen, U.S., Sillanpää, M.J. \& Juga, J. 2013. Across breed multitrait random regression genomic predictions in the Nordic Red dairy cattle. Journal of Animal Breeding and Genetics 130: 10-19.

Nokka, S. 2014. Tuotosseurannan tulokset 2013. Helsinki: ProAgria Finland. http://www.proagria.fi/sites/default/files/attachment/tuotosseurannan_tulokset_2013.pdf. Accessed 7 June 2014.

Perry, D, Yeates, A.P. \& McKiernan, W.A. 1993. Meat yield and subjective muscle scores in medium weight steers. Australian Journal of Experimental Agriculture 33: 825-831.

Pesonen, M., Honkavaara, M. \& Huuskonen, A. 2012. Effect of breed on production, carcass traits and meat quality of Aberdeen Angus, Limousin and Aberdeen AngusxLimousin bulls offered a grass silage-grain-based diet. Agricultural and Food Science 21: 361-369.

Pesonen, M., Honkavaara, M., Kämäräinen, H., Tolonen, T., Jaakkola, M., Virtanen, V. \& Huuskonen, A. 2013. Effects of concentrate level and rapeseed meal supplementation on performance, carcass characteristics, meat quality and valuable cuts of Hereford and Charolais bulls offered grass silage-barley-based rations. Agricultural and Food Science 22: 151-167.

Ruohomäki, H. 1976. Lihantuotantokokeiden tuloksia. Kotieläinjalostuksen tiedote no 12. Helsingin yliopisto, Kotieläinten jalostustieteen laitos \& Maatalouden tutkimuskeskus, Kotieläinjalostuslaitos. 15 p. (in Finnish). 